\title{
The POU proteins Brn-2 and Oct-6 share important functions in Schwann cell development
}

\author{
Martine Jaegle, ${ }^{1}$ Mehrnaz Ghazvini, ${ }^{1}$ Wim Mandemakers, ${ }^{1,3}$ Marko Piirsoo, ${ }^{1,4}$ Siska Driegen, ${ }^{1,2}$ \\ Françoise Levavasseur, ${ }^{1}$ Smiriti Raghoenath, ${ }^{1}$ Frank Grosveld, ${ }^{1}$ and Dies Meijer ${ }^{1,5}$ \\ Departments of ${ }^{1}$ Cell Biology and Genetics and ${ }^{2}$ Neurosciences, Erasmus University Medical Center, \\ 3000DR Rotterdam, Netherlands
}

\begin{abstract}
The genetic hierarchy that controls myelination of peripheral nerves by Schwann cells includes the POU domain Oct-6/Scip/Tst-1 and the zinc-finger Krox-20/Egr2 transcription factors. These pivotal transcription factors act to control the onset of myelination during development and tissue regeneration in adults following damage. In this report we demonstrate the involvement of a third transcription factor, the POU domain factor Brn-2. We show that Schwann cells express Brn-2 in a developmental profile similar to that of Oct-6 and that Brn-2 gene activation does not depend on Oct-6. Overexpression of Brn-2 in Oct-6-deficient Schwann cells, under control of the Oct-6 Schwann cell enhancer (SCE), results in partial rescue of the developmental delay phenotype, whereas compound disruption of both Brn-2 and Oct-6 results in a much more severe phenotype. Together these data strongly indicate that Brn-2 function largely overlaps with that of Oct-6 in driving the transition from promyelinating to myelinating Schwann cells.
\end{abstract}

[Keywords: POU domain; myelin; Schwann cell; nerve development]

Received December 20, 2002; revised version accepted April 10, 2003.

The high conduction velocity of nerve fibers is a hallmark of the nervous system of higher vertebrates and depends on structural and molecular specializations that are elaborated during development. These specializations occur through intimate and continued interactions between the neuron and its associated glial cells and result in the elaboration by glial cells of myelin, the important membranous structure that ensheaths and insulates axons (Arroyo and Scherer 2000; Fields and StevensGraham 2002; Mirsky et al. 2002). Two glial cell types produce myelin: the oligodendrocyte in the central nervous system (CNS) and the Schwann cell in the peripheral nervous system (PNS). Although very similarly organized, the molecular composition of CNS and PNS myelin differs significantly, and oligodendrocytes and Schwann cells have adopted different, but overlapping, sets of transcriptional regulators to coordinate myelogenesis (Hudson 2001; Topilko and Meijer 2001). These differences reflect their distinct embryonic origins. Whereas oligodendrocytes originate from the neuroepithelial precursors that line the lumen of the spinal cord

Present addresses: ${ }^{3}$ Department of Neurobiology, Stanford University School of Medicine, Stanford, CA 94305, USA; ${ }^{4}$ National Institute of Chemical Physics and Biophysics, Tallinn EE0026, Estonia.

${ }^{5}$ Corresponding author.

E-MAIL d.meijer@erasmusmc.nl; FAX 31-10-408-9468.

Article and publication are at http://www.genesdev.org/cgi/doi/10.1101/ $\operatorname{gad} .258203$. and ventricles of the brain, Schwann cells derive mainly from the neural crest, a transient embryonic stem (ES) cell population that generates a wide variety of cell types including sensory and autonomic neurons and melanocytes (Le Douarin and Kalcheim 1999; Richardson 2001). Schwann cell precursors populate the early outgrowing nerve bundles, where they proliferate and segregate individual and groups of fibers until the number of Schwann cells and fibers is eventually matched. During the first few days of postnatal development, many Schwann cells establish a 1:1 relationship with axons, cease to proliferate, and initiate myelin formation such that by the end of the first postnatal week of development, all myelin-competent axons are actively being myelinated. Schwann cells that remain associated with groups of lower-caliber fibers will segregate these fibers in cytoplasmic cuffs without myelinating them (Webster 1993). Although virtually nothing is known about the molecular identity of the axon-associated signal(s) that divert Schwann cells along either a myelinating or a nonmyelinating differentiation pathway, significant information has accumulated in recent years about the transcription factors involved in Schwann cell differentiation and myelination.

To date, several transcription factors have been found to be involved in the differentiation of Schwann cells and include the zinc-finger protein Krox20 (Egr-2), the Sry box protein Sox10, and the POU domain protein Pou3f1/ 
Oct-6/Scip/Tst-1 (referred to here as Oct-6; Topilko and Meijer 2001). Gene targeting experiments in mice have revealed insight into the functional roles of each of these factors and their possible order within a genetic hierarchy. Sox10 is required early in development for the establishment and/or maintenance of Schwann cell precursors from the neural crest (Britsch et al. 2001). At later stages of development, Oct- 6 and Krox 20 are both required for the differentiation of myelinating Schwann cells at two respective progressive steps in the genetic hierarchy (Topilko et al. 1994; Bermingham et al. 1996; Jaegle et al. 1996; Ghislain et al. 2002). During fetal development, Oct-6 gene expression is induced in immature Schwann cells and peaks in promyelinating and early myelinating cells during the first week of postnatal life (Scherer et al. 1994; Blanchard et al. 1996; Arroyo et al. 1998). Consequently, Oct- 6 regulates a set of downstream genes that includes Krox-20 (Blanchard et al. 1996; Ghislain et al. 2002). Krox-20 regulates an additional set of target genes including the major myelin genes and those involved in lipid metabolism (Nagarajan et al. 2001). In addition, Sox10 may continue to participate in these transcription programs, as it interacts with both Oct-6 and Krox20 when bound to adjacent DNAbinding sites (Kuhlbrodt et al. 1998b).

Schwann cell differentiation in nerves of Krox20 or Oct-6-deficient mice is arrested at the promyelin stage (Topilko et al. 1994; Bermingham et al. 1996; Jaegle et al. 1996). However, this differentiation block in Krox $20^{-/-}$ mice is permanent, and is transient in Oct-6 mutant animals (Oct- $\left.6^{\beta g e o / \beta g e o}\right)$. Thus, Oct- $6^{\beta g e o / \beta g e o}$ Schwann cells do eventually activate Krox20 expression and commence myelination, albeit with a delay of 7-10 d, thus suggesting some functional redundancy in the genetic program (Ghazvini et al. 2002). We previously proposed that the transient nature of the differentiation block is the result of an unknown Oct-6-like activity in Schwann cells, with this putative factor acting at a later developmental time than Oct-6 in the Schwann cell lineage (Jaegle and Meijer 1998). Alternatively, the transient block could be the result of a factor that regulates part or all of the transcriptional targets of Oct-6, but does so less efficiently. The most likely candidates for this Oct-6-like activity are the other members of the POU domain transcription factor family, of which there are 15 members in mammals (Ryan and Rosenfeld 1997). Interestingly, two POU domain transcription factors, Brn-1 and Brn-2, have virtually identical DNA-binding characteristics compared to Oct- 6 . Hence, to provide insight into the genetic program acting alongside Oct- 6 in promyelinating Schwann cells, we examined the expression and function of the candidate POU domain transcription factors during development and in Oct-6-deficient mice.

In this report, we show that Schwann cells express Brn-2 in a developmental profile similar to that of Oct-6. We demonstrate that Brn-2 gene activation is independent of Oct- 6 , but that Oct- 6 negatively regulates Brn-2 expression levels. Higher expression levels of Brn-2 in Oct-6 mutant Schwann cells result in a partial rescue of the developmental delay phenotype, whereas homozy- gous deletion of Brn-2 in Oct-6 mutant Schwann cells results in a more severe phenotype. Together these data strongly indicate that Brn-2 function largely overlaps with that of Oct- 6 in driving the transition from promyelinating to myelinating Schwann cells.

\section{Results}

Brn-2 is expressed and regulated in Schwann cells in a manner similar to Oct-6

The transient nature of the Schwann cell defect in Oct6-deficient mice suggested some redundancy in transcription factor function. Interestingly, previous work on the expression of octamer binding factors Oct- 6 and Oct-1 in the developing chick sciatic nerve suggested the presence of a novel octamer-binding activity and possibly a homologous candidate factor involved in developing mouse sciatic nerves (Levavasseur et al. 1998). Hence, to examine the developmental expression profile of this novel binding activity, we performed electrophoretic mobility shift assays (EMSAs) using whole sciatic nerve extracts derived from chick embryos and young chicks. Three complexes can be distinguished (Fig. 1A). The largest complex contains Oct-1, a ubiquitous POU factor, the levels of which are relatively constant at all stages of nerve development (Blanchard et al. 1996). In contrast, the smallest and fastest migrating Oct-6-containing complex is strongly regulated during development. Like in rodents, Oct-6 expression peaks in promyelinating and early myelinating cells (embryonic day 17 and 20; E17 and E20 in Fig. 1A) and is sharply downregulated at later stages of myelination (postnatal day 3; $\mathrm{P} 3)$. The third, intermediate complex (X) is regulated similarly to Oct-6, but its expression is maintained at reduced levels at later stages (P20 in Fig. 1A). Using different octamer-related DNA-binding sites, such as the HSV1 TAATGARAT motif, and a mutated octamer motif, we found that this novel activity demonstrated binding site preferences very similar to those of Oct-6 (data not shown).

To identify the protein in this complex, we performed EMSA experiments in the presence of antisera against several POU proteins closely related to Oct-6. Although the mobility or intensity of the intermediate complex X was not affected by antibodies against the chicken Oct- 6 protein (Fig. 1B, middle lane), a Brn-2-specific goat antiserum strongly reduced the intensity of this complex, thus identifying the protein in the intermediate complex as Brn-2 (Fig. 1B, right lane).

Until recently, expression of Brn-2 in mammalian peripheral nerves had not been described and, paradoxically, only one octamer complex, in addition to Oct-1, had been observed in cultured rat Schwann cells (Kuhn et al. 1991; Sim et al. 2002). Therefore, we next examined the presence of Brn-2-binding activity in the developing sciatic nerve of the mouse at P4 by EMSA. In accordance with previous data, only one prominent protein/DNA complex, in addition to the Oct-1/DNA complex, was observed (Fig. 1C, lane 1). However, in supershift assays 
A

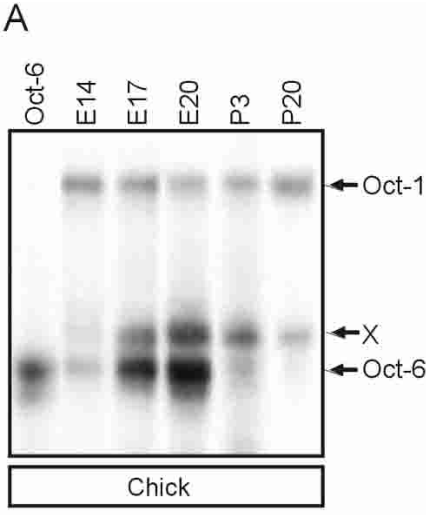

B

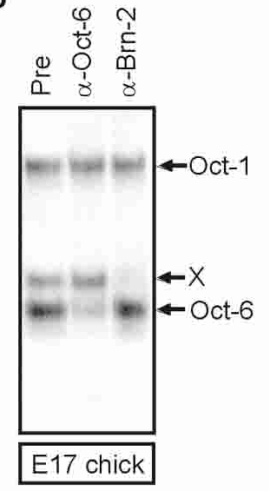

C

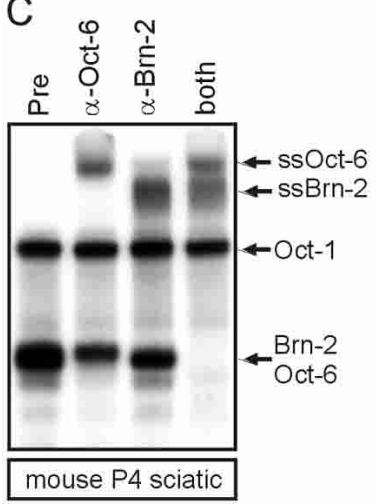

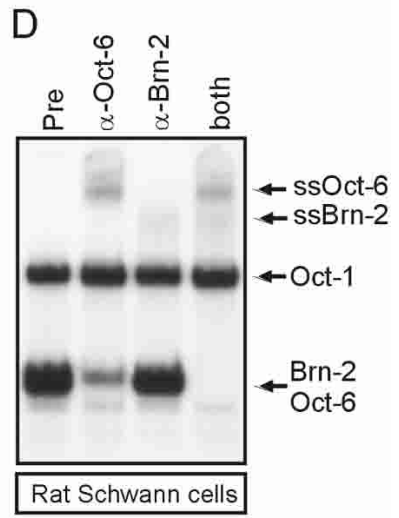

Rat Schwann cells

Figure 1. Brn-2 is expressed in chick and mouse sciatic nerves. (A) Developmental expression of a novel octamer-binding complex was examined by EMSA using freeze-thaw extracts from chicken nerves at different stages of development [embryonal stages E14, E17, and E20 and postnatal days 3 (P3) and 20 (P20)]. Whole-cell extracts of COS cells expressing chicken Oct-6 (Oct6) served as a control (Meijer et al. 1990). Free probe is not shown, but all experiments were performed in probe excess. (B) Using E17 chick embryonic nerve, extracts identify Brn-2 in complex $\mathrm{X}$, as antibodies directed against the C-terminal part of mouse Brn-2 specifically affect complex $\mathrm{X}$, whereas chicken Oct- 6 antibodies $(\alpha$-Oct- 6$)$ affect the Oct- 6 complex but not complex X. Preimmune serum (Pre) does not affect either complex. $(C)$ Brn-2 is expressed in mouse nerves. Incubation of Oct6-specific antibodies with P4 mouse whole-nerve extracts and an octamer probe results in the formation of a ternary complex (supershift Oct-6 complex; ssOct-6) and unmasks another complex that is specifically supershifted (ssBrn-2) with mouse Brn-2 antibodies $(\alpha-B r n-2)$. When both antibodies are added all complexes are shifted, demonstrating that no other complexes comigrate with the Oct-6/DNA and Brn-2/DNA complexes. $(D)$ Brn-2 is expressed in the Schwann cell lineage. Whole-cell extracts from cultured rat Schwann cells grown in the presence of $20 \mu \mathrm{M}$ forskolin for $36 \mathrm{~h}$ were incubated with the octamer probe in presence of the indicated sera. As in C, Oct-6- and Brn-2specific antibodies identify two comigrating Oct- 6 and Brn-2 protein DNA complexes.

using antibodies specific for Oct- 6 and Brn-2, this band was found to be composed of two complexes, a Brn-2/ DNA complex and an Oct-6/DNA complex (Fig. 1D, lanes 2-4). Thus, Brn-2 protein is expressed in both the developing chick and murine nerve.

Because sciatic nerve extracts are heterogeneous, it is possible that Brn-2 is expressed exclusively in cell types other than Schwann cells, such as endothelial or perineural cells. We therefore examined expression of Brn-2 in pure differentiating primary rat Schwann cell cultures using EMSA (Fig. 1D). These cells express high levels of Oct-6 and moderate levels of Brn-2 (Fig. 1D, cf. lanes 2 and 3). Thus, Brn-2 is expressed in the Schwann cell lineage and is therefore an attractive candidate for the putative Oct-6 like function.

\section{Brn-2 is expressed in Oct-6-deficient Schwann cells}

We next examined whether Brn-2 expression is affected by loss of Oct- 6 function in Schwann cells. As the vast majority of full Oct-6 knockout animals (Oct- $6^{\text {Bgeo/Bgeo) }}$ are not viable and die shortly after birth, thus precluding studies at postnatal stages of development, we used in this study animals that carry on one chromosome a full knockout allele ( $\beta$ geo) and on the other chromosome a Schwann cell-specific Oct-6 strong hypomorphic allele ( $\triangle$ SCE; Ghazvini et al. 2002). The Oct- $6^{\Delta S C E}$ allele was generated through deletion of the Oct-6 Schwann cell enhancer (SCE; Mandemakers et al. 2000). Both Oct- $6^{\triangle S C E / \triangle S C E}$ and Oct- $6^{\beta g e o / \Delta S C E}$ mice are viable and exhibit a peripheral nerve phenotype that is indistinguishable from that observed in nerves of Oct- $6^{\text {Bgeo/Bgeo }}$ animals (Ghazvini et al. 2002).

Using EMSA and Western blotting, we analyzed Brn-2 expression in the developing nerve of Oct-6 $6^{\text {Bgeo/ }} \Delta S C E$ mice (Fig. 2). In addition to the expected Oct-1 complex, one abundant octamer complex is observed. Supershift experiments using Oct-6- and Brn-2-specific antibodies identify Brn-2 as the major protein component in this complex (Fig. 2A, cf. lanes 2 and 3), with only very low levels of Oct- 6 protein detected, in agreement with previous data (Ghazvini et al. 2002). Both EMSA and Western blot analyses demonstrate that Brn-2 protein levels are increased in Oct- $6^{\beta g e o / \triangle S C E}$ nerves at P4 compared to heterozygous or wild-type nerves (Fig. 2A,B). The higher Brn-2 protein levels in Oct-6-deficient nerves result from increased transcription of the Brn-2 gene (or increased Brn-2 mRNA stability), as reverse transcriptase PCR (RT-PCR) data for Brn-2 expression in P1 mice show that steady-state levels of Brn-2 mRNA are increased in Oct$6^{\beta g e o / \Delta S C E}$ nerves compared to Oct- $6^{\Delta S C E /+}$ nerves (Fig. $2 \mathrm{C})$. Immunostaining of single nerve fibers shows that within the nerve, Brn-2 is highly expressed in Schwann cell nuclei (Fig. 2D).

Next we examined developmental regulation of Brn-2 protein expression in nerves of Oct- $6^{\Delta S C E /+}$ and Oct$6^{\beta g e o / \Delta S C E}$ mice, using Western blotting (Fig. 2E). In heterozygous animals, Brn-2 expression is up-regulated in the late embryonic nerve and peaks during the first postnatal week of development. At later stages (P32), Brn-2 expression is extinguished. Thus, in both chick and mouse, Oct- 6 and Brn-2 are similarly regulated, although Brn-2 down-regulation appears to be faster in mice. In Oct-6 mutant nerves, Brn-2 expression appears to be affected in two ways. First, overall Brn-2 expression levels 
A

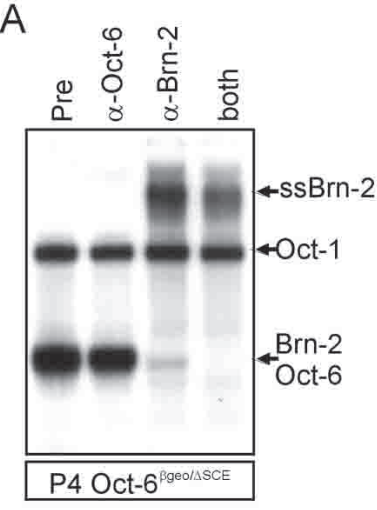

B

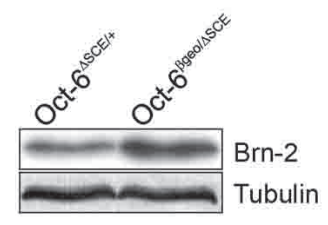

C

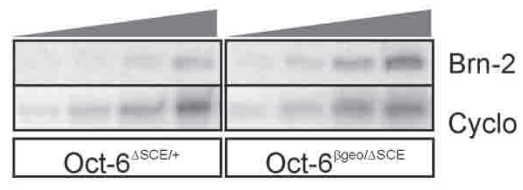

$\mathrm{D}$

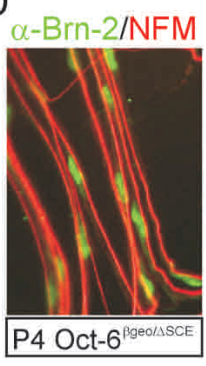

E

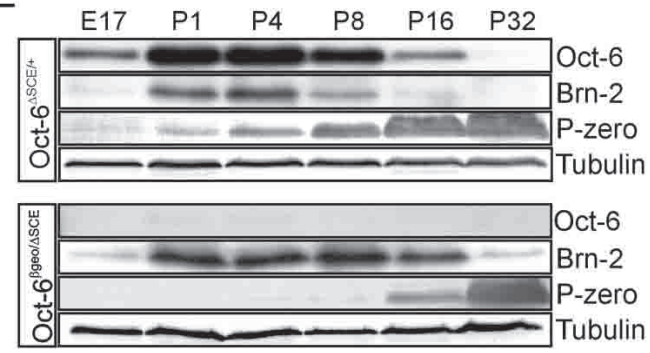

Figure 2. Elevated and protracted expression of Brn-2 in nerves of Oct-6 $6^{\beta g e o / \Delta S C E}$ mice. (A) EMSA with whole-cell extracts from sciatic nerves of $\mathrm{P} 4 \mathrm{Oct}-6^{\beta g e o / \Delta S C E}$ mice and a radiolabeled octamer probe reveal a strong complex that migrates at the same position as Brn-2 and Oct-6 DNA complexes. This complex is supershifted with antibodies against Brn-2, unmasking the low residual expression of Oct- 6 from the $\triangle$ SCE allele. Preimmune serum affects none of these complexes. $(B)$ Western blot analysis confirms that Brn-2 protein levels are elevated in the nerves of Oct- $6^{\beta g e o / \Delta S C E}$ vs. Oct- $6^{\Delta S C E /+}$ nerves at P4. Tubulin served as a loading control. (C) Semiquantitative RT-PCR using RNA extracted from newborn sciatic nerves shows the higher Brn-2 mRNA steady-state levels in Oct-6 $6^{\text {Bgeo/ }} \triangle S C E$ mice than in Oct- $6^{\triangle S C E /+}$ mice. Cyclophilin mRNA served as a control. $(D)$ Brn-2 is expressed in the nucleus of Schwann cells in the nerves of P4 Oct- $6^{\beta g e o / \Delta S C E}$ mice. Nerves were dissected and teased into single fibers and incubated with antibodies against mouse Brn-2 ( $\alpha-B r n-2)$ in green and Neurofilament medium chain (NFM) in red. (E) Expression of Brn-2 and Oct- 6 was examined in developing nerves of Oct- $6^{\Delta S C E /+}$ and Oct- $6^{\beta g e o / \Delta S C E}$ animals at E17 and P1-P32. Amounts of nerve extract loaded were normalized for acetylated $\alpha$-tubulin. The build-up of P-zero immunoreactivity over time illustrates the progression of myelination in both genotypes. are increased (see also Fig. 2A,B). Second, whereas upregulation of Brn-2 expression follows its normal course, down-regulation of Brn-2 expression is protracted, with significant levels of Brn-2 still present at P32. In both Oct- $6^{\Delta S C E /+}$ and Oct- $6^{\text {Bgeo/ } \triangle S C E}$ genetic backgrounds, down-regulation of Brn-2 correlates with the build up of P-zero immunoreactivity, indicating that a myelinationassociated signal, which is independent of Oct-6, extinguishes Brn-2 expression.

Together, these data demonstrate that the developmental profile of Brn-2 expression in the nerve is regulated through mechanisms independent of Oct-6, but that Brn-2 expression levels are negatively attenuated by Oct-6.

\section{Role of Brn-2 in Schwann cell development and myelination}

Considering the findings that Brn-2 is expressed at relatively high levels in Oct-6-deficient Schwann cells that are transiently blocked in their differentiation, and that Brn-2 DNA-binding characteristics are virtually identical to those of Oct-6, one can suggest several possible roles for Brn-2 in Schwann cells. First, it is possible that Brn- 2 regulates the same repertoire of genes as Oct- 6 but does so less efficiently, possibly because of different affinities for Oct- 6 interacting factors important in target gene regulation. Second, it is possible that Brn-2 function only partially overlaps with Oct-6 and/or that yet another factor, which might be activated at a later developmental time, is responsible for the delayed activation of the myelination program in the absence of Oct-6. It was recently proposed that the POU homeodomain pro- tein Brn-5, a class VI POU protein, might fulfill such a role (Wu et al. 2001). This factor is activated at a later developmental time than Oct- 6 and Brn-2, and its activation does not depend on Oct- 6 . Third, it is possible that Brn-2 negatively regulates Oct- 6 targets, possibly through its interaction with the homopolymeric glutamine tract binding protein PQBP-1 (Waragai et al. 1999), and that the balance between Oct- 6 and Brn- 2 governs the progression of cells into the myelinating phase of differentiation. In the absence of Oct- 6 this balance shifts to Brn-2, and cells are inhibited in their differentiation. Thus, to begin to explore the possible roles of Brn-2 and Brn-5 in Schwann cell differentiation, we performed transgenic mouse experiments in which Brn-2 or Brn-5 is overexpressed in the Schwann cell lineage.

To direct expression of Brn-2 or Brn-5 in Schwann cells, we made use of the Oct-6 SCE (Fig. 3A). This genetic element drives transgene expression from a generic promoter in Schwann cells with a profile that is identical to that of Oct- 6 and very similar to that of Brn- 2 but not Brn-5 (Mandemakers et al. 2000). We previously showed that a transgenic construct carrying the SCE and an HAtagged version of Oct- 6 rescues the delay in development of the peripheral nerve in Oct-6-deficient mice (Mandemakers et al. 2000). To test whether Brn- 2 or Brn-5 overexpression can replace Oct-6 in this rescue, we generated transgenic lines for the three constructs depicted in Figure 3A. These transgenes were subsequently crossed into an Oct- $6^{\beta g e o / \triangle S C E}$ background, and nerve maturation at P4 was studied by Western blotting and light microscopy (Fig. 3B,C). Additionally, we counted the number of promyelin and myelinating configurations in these nerves and expressed the fraction of myelinating figures divided 
Jaegle et al.
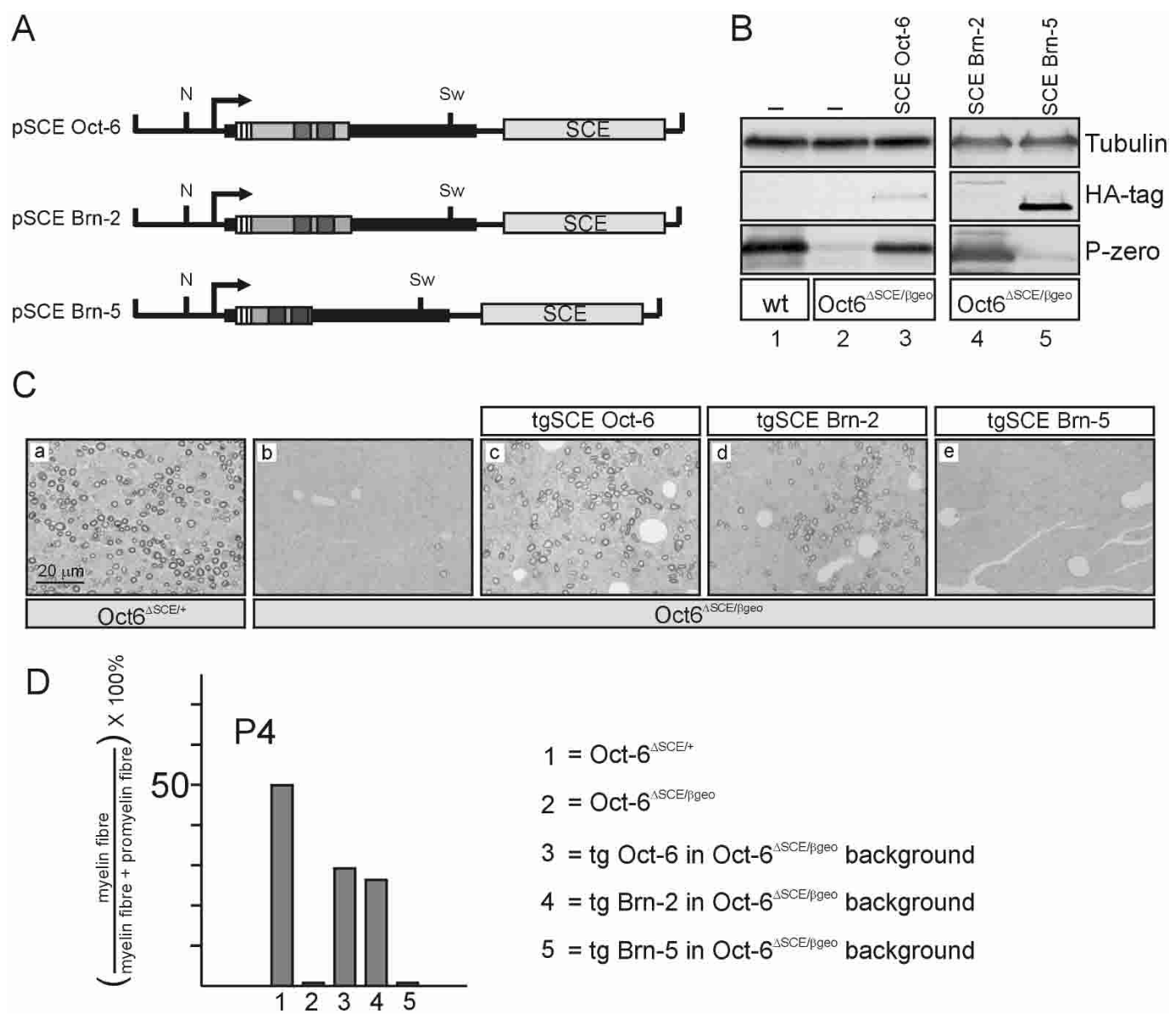

$$
\begin{aligned}
& 1=\text { Oct- } 6^{\text {\SCE } /+} \\
& 2=\text { Oct }-6^{\text {ASCE } / \text { Bgeo }} \\
& 3=\operatorname{tg} \text { Oct- } 6 \text { in Oct- } 6^{\text {\SCE/igeo }} \text { background } \\
& 4=\operatorname{tg} \text { Brn-2 in Oct- } 6^{\triangle S C E / \beta g e O} \text { background } \\
& 5=\operatorname{tg} \text { Brn-5 in Oct- } 6^{\text {\SCE } / \text { geoo }} \text { background }
\end{aligned}
$$

Figure 3. HA-Oct-6 and HA-Brn-2, but not HA-Brn-5, can rescue the developmental delay phenotype of Oct- $6^{\beta g e o / \Delta S C E}$ mutant mice. (A) Schematic representation of the constructs used to generate mice transgenic for HA-Oct-6 (SCE Oct-6), HA-Brn-2 (SCE Brn-2), and HA-Brn-5 (SCE Brn-5). Two restriction sites used in the generation of these constructs are indicated [NotI (N) and SwaI (Sw)]. The SCE is indicated as a gray box and the triple HA-tag as a yellow box. The intron-less Oct-6 gene is shown as a thick black line. The ORF of Oct-6 is in light green, that of Brn-2 is in pink, and that of Brn-5 is in orange, with their POU-specific domain in dark blue and their POU-homeodomain in light blue. (B) Oct-6 $6^{\beta g e o / \Delta S C E}$ mutant mice that express HA-Oct-6 or HA-Brn-2 show high levels of P-zero protein expression in sciatic nerve. Western blot analysis of $\mathrm{P} 4$ sciatic nerve extracts from wild-type (wt; lane 1$),$ Oct- $6^{\beta g e o} / \Delta S C E($ lane 2), Oct-6 $6^{\beta g e o} / \Delta S C E / S C E$ Oct-6 (lane 3), Oct-6 $6^{\beta g e o / \Delta S C E} / S C E$ Brn-2 (lane 4), and Oct-6 $6^{\beta g e o / \Delta S C E} / S C E$ Brn-5 (lane 5) animals. Levels of HA-tagged proteins are assessed with $\alpha$-HA antibodies. The amount of protein loaded per lane is estimated by the intensities of the $\alpha$-tubulin immunoreactive band. $(C)$ Comparison of the morphology of cross sections through P4 sciatic nerves of Oct-6 $6^{\Delta S C E /+}($ panel

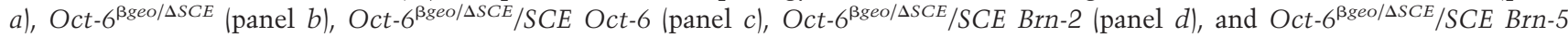
(panel $e$ ) animals. Plastic-embedded osmicated nerves were sectioned at $1 \mu \mathrm{m}$ and stained with ppd. Myelin is strongly stained by this compound and appears as dark rings in cross sections. Bar, $20 \mu \mathrm{m} .(D)$ Quantification of the promyelin-myelinating transition in nerves of animals in $C$.

by the total number of myelinating and promyelin configurations to obtain a quantitative measure of nerve maturation (Fig. 3D). In the absence of Oct-6, all but a few myelinating Schwann cells are stalled at the promyelin stage of differentiation [Fig. 3C (cf. panels a and b), $3 \mathrm{D}(50 \%$ and $0.5 \%)]$, and P-zero protein levels are very low (Fig. 3B, cf. lanes 1 and 2) compared to heterozygous or wild-type animals. Expression of the HA-Oct-6 transgene results in a significant restoration of P-zero protein levels in nerves of Oct- $6^{\beta g e o /} \triangle S C E$ mice (Fig. 3B, lane 3). At the morphological level, this finding correlates with increased numbers of myelinating Schwann cells, up to $60 \%$ of wild-type (Fig. 3C, panel c, 3D). Expression of the HA-Brn-2 transgene also results in significant restora- tion of P-zero protein levels (Fig. 3B, lane 4) and a strong increase in the numbers of actively myelinating Schwann cells (Fig. 3C, panel d, 3D). In contrast, the HA-Brn-5 transgene is not capable of restoring P-zero protein levels (Fig. 3B, lane 5) and accordingly, no increase in the number of myelinating cells is observed (Fig. 3C, panel e) despite relatively high levels of HABrn-5 expression (Fig. 3B, lane 5). Thus, increased Brn-2 expression in early postnatal development results in a significant increase in the number of actively myelinating Schwann cells in transgenic SCE Brn-2/Oct-6 $6^{\beta g e o / \Delta S C E}$ nerves. This number approaches that observed in nerves of transgenic SCE Oct-6/Oct-6 $6^{\beta g e o / \triangle S C E}$ animals (Fig. $3 \mathrm{D})$. These results demonstrate that Brn-2 does not an- 
tagonize Oct- 6 function, but instead functionally substitutes for Oct- 6 in promoting the transition from promyelinating to myelinating Schwann cells. Furthermore, our results suggest that Brn-2 levels are rate-limiting in Schwann cells of Oct- $6^{\beta g e o / \Delta S C E}$ mice.

\section{Schwann cell-specific deletion of Brn-2 does not affect peripheral nerve development}

The experimental results described above suggest that Brn- 2 and Oct- 6 share many transcriptional targets, but do not reveal whether Brn-2 has distinct (non-Oct-6) regulatory targets. In addition, the above experiments do not exclude that other, as yet unidentified transcription factors, contribute to the delayed entry of Oct- $6^{\beta g e o / \Delta S C E}$ Schwann cells into the myelinating phase of differentiation. To address these questions we examined the effect of loss of Brn-2 function in the Schwann cell lineage. A full null allele of Brn-2 had been generated previously and revealed a vital function for Brn-2 in the development and survival of endocrine neurons in the hypothalamus (Nakai et al. 1995; Schonemann et al. 1995). As a consequence, the hypothalamic-pituitary axis is disturbed and homozygous animals die before postnatal day 10. Therefore, we generated mice carrying a conditional null allele of Brn-2 in which deletion of the LoxP-flanked Brn-2 open reading frame (ORF; Fig. 4A) depends on activity of the Cre recombinase in Schwann cells. The introduction of LoxP sites at the Brn-2 locus, together with a neomycin selection cassette and an eGFP reporter, did not compromise Brn-2 gene function, as Brn-2 flox/flox animals are healthy and breed normally.

To achieve Schwann cell-specific deletion of the Brn-2 gene, we generated transgenic mouse lines in which the Cre recombinase is expressed from Desert hedgehog (Dhh) regulatory sequences (Fig. 4B). The Dhh gene is prominently expressed in Schwann cell precursors of the developing nerves and in Sertoli cells of the testis (Bitgood and McMahon 1995). The cell-type specificity of the recombination event was monitored in offspring of crosses between the DhhCre transgenic mice and ROSA26 LacZ reporter (Soriano 1999). Embryos were isolated from these crosses at different developmental stages and stained with Bluo-Gal for $\beta$-galactosidase activity. DhhCre activity was observed in the Schwann cell lineage from E12, as evidenced by blue staining of the peripheral nerves (Fig. 4B, panels a,b). DhhCre activity is also observed in the testis, another well documented site of Dhh gene expression. Outside the Schwann cell lineage and testis, expression of Cre is ob-
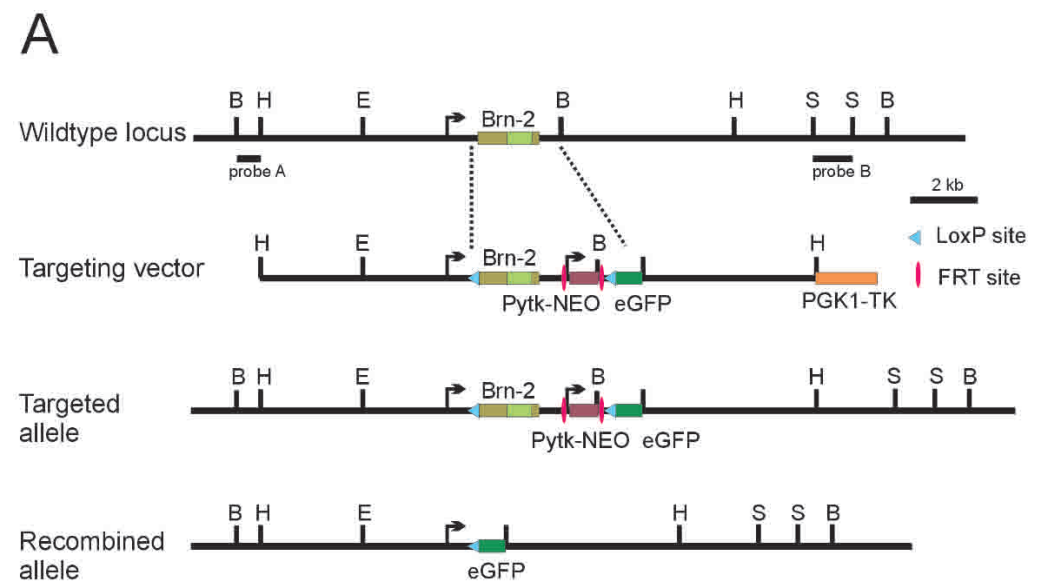

B
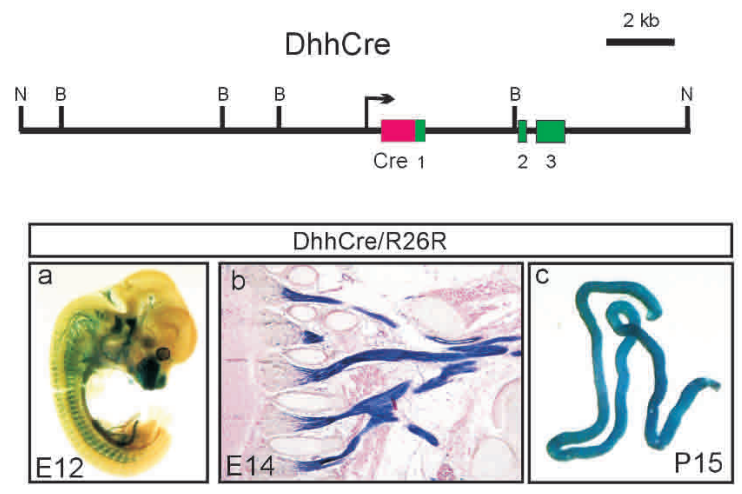

Figure 4. (A) The targeting strategy to generate an inducible deletion allele of Brn-2. The structure of the wild-type Brn-2 locus is shown at the top. The $B r n-2$ single exon gene is represented in olive green with the POU domain in light green. The Southern blot probes $\mathrm{A}$ and $\mathrm{B}$ are indicated as horizontal black bars. The positions of restriction enzyme cutting sites are shown for BamHI (B), HindIII $(\mathrm{H})$, EcoRI (E) and ScaI (S). In the targeting construct (targeting vector), the neomycin (NEO) expression cassette (purple box) is flanked by FRT sites (vertical red bars) followed by a 3' LoxP site (blue triangle) and an eGFP reporter gene (dark green box). The orange box represents the counter-selection cassette, containing the thymidine kinase gene (TK). The targeted allele (the floxed allele) obtained after homologous recombination is shown below the targeting construct. Cre-mediated recombination removes Brn-2 sequences and generates the recombined allele (bottom). (B) Schwann cell-specific recombination is achieved through expression of the Cre recombinase under control of Dhh gene regulatory sequences. The $19-\mathrm{kb}$ construct containing the entire Dhh gene with its three exons (in green) is shown. The Cre recombinase ORF (indicated in red) is preceded by a nuclear localization peptide sequence and cloned in-frame with the Dhh ORF. Restrictions sites for NotI (N) and BamHI (B) are indicated. Expression of the Cre recombinase was examined in crossing with the ROSA26lacz (R26R) reporter mouse. (Panel a) Whole-mount staining of E12.5 embryo reveals expression in the PNS, the snout, and part of the vasculature. (Panel b) Paraffin sections of a stained E14.5 embryo demonstrate the strong expression in immature Schwann cells that populate the peripheral nerves. (Panel $c$ ) Strong expression is also observed in the seminiferous tubules of the testis, where Dhh is expressed in the Sertoli cells. 
served in the skin of the snout, but not in the brain and more specifically the hypothalamic region.

To explore the effect of loss of Brn-2 expression in the Schwann cell lineage, we crossed the DhhCre transgene into the Brn-2 flox/flox background. Offspring from these crosses were healthy and bred normally. Southern blot analysis of DNA derived from sciatic nerves of adult DhhCre/Brn- $2^{\text {flox/flox }}$ animals revealed that the majority of cells had undergone recombination [cf. the ratio of the 14-kb band (recombined) and the 8.3-kb (not recombined) band in Fig. 5A, lane 4]. The nonrecombined band derives from non-Schwann cells in the nerve that do not express the DhhCre transgene. Recombination within the Schwann cell compartment of the nerve was complete, as judged by the complete loss of Brn-2 expression in nerves of transgenic DhhCre/Brn-2 flox/flox pups using EMSA (Fig. 5B, cf. lanes 1 and 2). Additionally, loss of
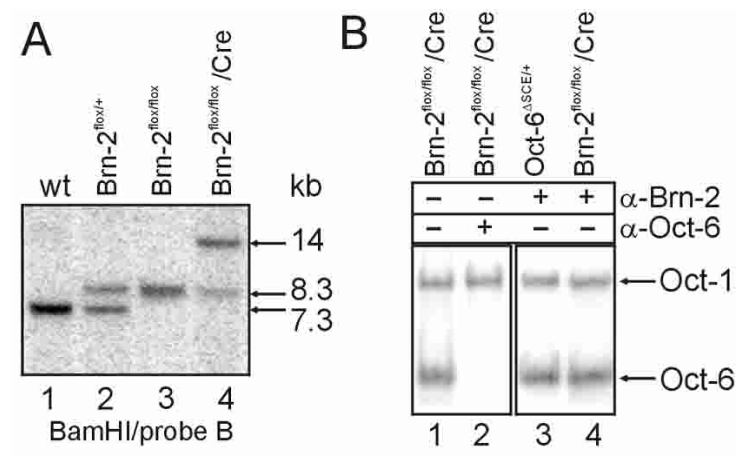

C

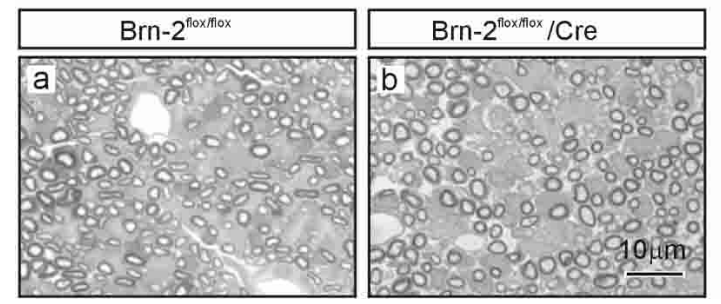

Figure 5. (A) The floxed Brn-2 locus is effectively recombined by the Cre recombinase in peripheral nerve. DNA was extracted from adult sciatic nerve of wild-type (wt), Brn-2 $2^{\text {wt/flox }}, B r n-2^{\text {flox } / f l o x}$, and Brn-2 ${ }^{\text {flox/flox }}$ Cre (Brn-2 flox/flox mice transgenic for the DhhCre transgene) animals, digested with BamHI, and subjected to Southern blot analysis with probe B. Probe B detects fragments of $7.3 \mathrm{~kb}$ (wild-type allele), $8.3 \mathrm{~kb}$ (targeted allele), and $14 \mathrm{~kb}$ (recombined allele). The nonrecombined band present in lane 4 results from DNA derived from cells that do not express the DhhCre transgene, such as nerve sheath cells. $(B)$ The recombination of the Brn-2 allele in Schwann cells is complete, as Brn-2 ${ }^{\text {flox/flox }}$ Cre nerves do not express Brn-2 atP4 (lanes 1,2). Complete deletion of Brn-2 does not affect Oct- 6 expression, as Oct-6 expression levels are the same in nerves of Oct-6 $6^{\Delta S C E /+}$ and Brn-2 flox/flox Cre animals (cf. lanes 3 and 4). (C) Deletion of Brn-2 in Schwann cells does not affect the morphological maturation of the nerve. The overall morphology appears very similar in cross sections of nerves from both genotypes. Resin sections $(1 \mu \mathrm{m})$ of $\mathrm{P} 4$ sciatic nerves of Brn-2 flox/flox (panel a) and Brn-2 flox/flox $/ C r e($ panel $b$ ) animals were stained with ppd. Bar, $10 \mu \mathrm{m}$ (applies to both micrographs).
Brn-2 did not affect Oct-6 expression levels in these nerves compared with age-matched $\mathrm{Oct}-6^{\Delta S C E /+}$ nerves (Fig. 5B, cf. lanes 3 and 4). We next examined the effect of complete loss of Brn-2 expression in Schwann cells on nerve development. Light microscopic examination of sciatic nerves of P8 transgenic DhhCre/Brn- $2^{\text {flox/flox }}$ animals did not reveal clear morphological abnormalities (Fig. 5C). In both Brn-2 flox/flox and DhhCre/Brn- $2^{\text {flox/flox }}$ nerves, the majority of Schwann cells associated with larger axons are actively myelinating. Thus, loss of Brn-2 expression in the Schwann cell lineage does not affect the timing or progression of postnatal peripheral nerve development.

\section{Schwann cell-specific deletion of Brn-2 and Oct-6 results in a severe hypomyelinating phenotype}

To study the role of Brn-2 in Schwann cells deficient for Oct-6, we generated double homozygous mutants by intercrossing transgenic DhhCre/Brn-2 flox/flox $/ O c t-6^{\Delta S C E / \Delta S C E}$ and transgenic DhhCre/Brn- $2^{\text {flox/flox }} /$ Oct- $6^{\text {Bgeo/+ }}$ mice. The development of peripheral nerves was examined by electron microscopy and quantified as described above. In the absence of Oct- 6 function, Schwann cell development is transiently blocked at the promyelin stage (Bermingham et al. 1996; Jaegle et al. 1996; Ghazvini et al. 2002). Whereas $>90 \%$ of large-caliber axons in nerves of wild-type (data not shown) and heterozygous Oct$6^{\triangle C S E /+}$ animals are myelinated by the third postnatal week (at P16), nerves of Oct- $6^{\text {Bgeo/ } \triangle S C E}$ mice still contain many promyelin configurations (Fig. 6A, panels a,b, 6B, $\sim 60 \%$ ). A dramatic increase in the severity of this phenotype is observed with the Schwann cell-specific deletion of Brn-2 on the Oct- $6^{\beta g e o / \Delta S C E}$ genetic background. As shown in Figure 6A, panel c, none of the ensheathing Schwann cells has progressed beyond the promyelin stage of differentiation. To determine whether these cells are permanently blocked in their differentiation, nerve morphology in young adult animals was examined at P56 and P120. At these stages most, if not all, Oct$6^{\beta g e o / \triangle S C E}$ Schwann cells have gone on to myelinate their associated axon [Fig. 6A (cf. panels d and e), 6B]. In contrast, nerves of double homozygous animals are abnormal, with many promyelin configurations $(-55 \%$ at $\mathrm{P} 56$ to $\sim 25 \%$ at $\mathrm{P} 120$ ) and thinly myelinated axons (Fig. 6A, panels $\mathrm{f}, \mathrm{i})$. This morphology resembles that of wild-type nerves during the first week of postnatal development. Therefore, deletion of both Oct-6 and Brn-2 results in further delay in the promyelinating-myelinating transition relative to that observed in single Oct-6 mutants, indicating that, in addition to Oct- 6 , Brn- 2 plays a role in the transition of promyelinating to myelinating Schwann cells.

\section{Discussion}

In the present study we have shown that the class III POU domain protein Brn-2 is regulated in parallel with Oct-6 during Schwann cell differentiation. As the previ- 
A

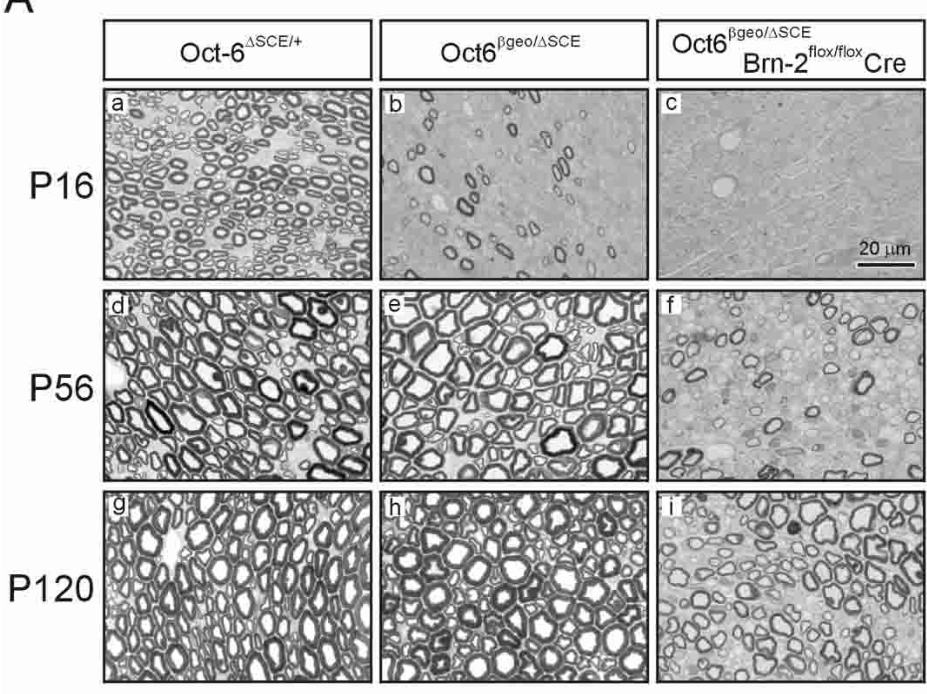

B

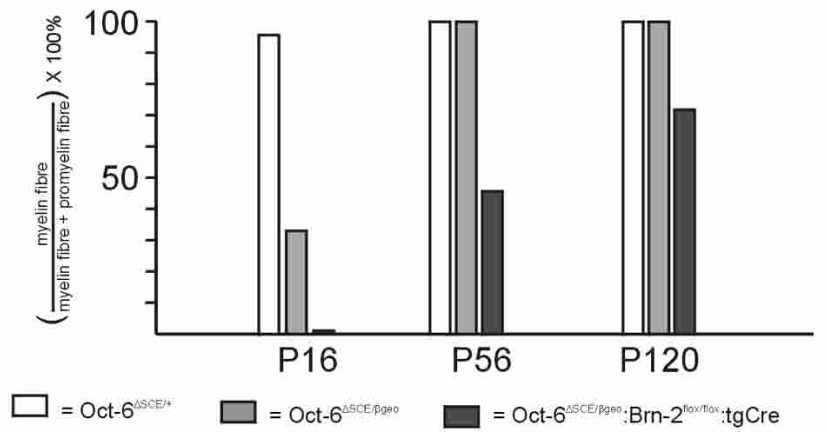

Figure 6. Schwann cell-specific deletion of Brn-2 in an Oct- $6^{\beta g e o / \triangle S C E}$ background results in a severe hypomyelination phenotype. (A) Representative sections (1 $\mu \mathrm{m}$; ppdstained) are shown from sciatic nerves at three developmental time points (P16, P56, and P120). In Oct-6 $6^{\Delta S C E /+}$ mice, most myelin-competent axons are actively being myelinated by P16 (panel $a$ ). At P56 and P120, these nerves are fully matured (panel $d$ ). This pattern contrasts with that observed in Oct- $6^{\beta g e o / \Delta S C E}$ animals, which exhibit a strong delay in the differentiation of Schwann cells (Bermingham et al. 1996; Jaegle et al. 1996; Ghazvini et al. 2002). At P16, a majority of Schwann cells is arrested at the promyelin stage, with only the largest axons myelinating (panel $b$ ). By P56, most if not all myelinating Schwann cells have elaborated a myelin sheath (panels $e, h$; P120). Deletion of Brn-2 in this genetic background results in a dramatic increase in the severity of the phenotype. At P16, essentially all myelinating Schwann cells are arrested at the promyelin stage of differentiation (panel c). Even at P56 and P120, myelination is largely abnormal, with large numbers of cells at the promyelin stage (panel $f$ ). Those axons that are myelinated have very thin myelin sheaths. Bar: panels $a-f, 20 \mu \mathrm{m}$. (B) Quantification of delayed myelination in genotypes presented in $A$. ous data on the delayed myelination phenotype of Oct6-deficient mice suggested a redundant activity, we show here that Brn-2 acts as that novel factor. Our genetic evidence, arising from the overexpression of Brn-2 in Oct-6-deficient mice and moreover, the double deficiency of Brn-2 and Oct- 6 , demonstrates that these POU domain transcription factors share roles as positive regulators of the promyelinating-myelinating transition in Schwann cell development. Considering the importance of peripheral nerve myelination, the activity of both these transcription factors most likely assures the progression of this process.

\section{Regulation of Brn-2 expression in the Schwann cell lineage}

Our studies on chick and mouse sciatic nerve at different embryonic and post-hatching or postnatal stages showing that Oct- 6 and Brn-2 are regulated similarly during nerve development provided a strong suggestion that Brn-2 plays a role in the onset of myelination. Both genes are activated around the time that most Schwann cells have adopted an immature promyelinating phenotype (E14 in the chick and E17 in the mouse). Expression of both genes peaks in promyelinating Schwann cells and is down-regulated in actively myelinating cells. Using cultured rat Schwann cells as a convenient in vitro system, we found that both Brn-2 and Oct- 6 expression is increased upon addition of forskolin (an agent that elevates intracellular cAMP concentration through the reversible activation of adenylyl cyclase; Fig. 1D). Similarly, during nerve regeneration, Sim and colleagues (2002) showed the parallel expression of Brn-2 and Oct-6. Our present studies of Oct-6- and Brn-2-deficient mice demonstrate that the activation of these genes is not interdependent, thus providing a safeguard for myelination in the developing organism.

Intracellular signaling pathways that regulate Oct- 6 expression in Schwann cells converge on the SCE, an enhancer element that has been identified in both the mouse and human Oct- 6 locus. A first attempt to identify such an enhancer within the Brn-2 locus on the basis of sequence homology has failed thus far. DNaseI hypersensitivity mapping of the Brn-2 locus in Schwann cells should suggest the position of relevant enhancer sequences and facilitate the identification of relevant binding sites within the enhancers of Oct- 6 and Brn-2, so as to determine whether the activation of these genes is by means of a similar signaling pathway. One signaling 
pathway that is of particular interest in this respect is the NFкB pathway, as Nickols and colleagues (2003) recently provided evidence of its involvement in peripheral nerve myelination and Oct- 6 regulation in Schwann cells.

Although Oct- 6 and Brn-2 are activated independently, Brn-2 expression levels are attenuated by Oct-6. Brn-2 expression levels are increased (two- to threefold) in Oct6-deficient Schwann cells compared to wild-type (Figs. $1 \mathrm{C}, 2 \mathrm{~A}, \mathrm{~B})$. It is at present not known by what mechanism Brn-2 levels are regulated by Oct-6, although our semiquantitative RT-PCR data suggest involvement of transcriptional or posttranscriptional mechanisms rather than translational or posttranslational mechanisms. Brn-2 expression is extinguished through an Oct-6-independent pathway, as Brn-2 expression is down-regulated at later stages of postnatal development, even in the absence of Oct-6 (Fig. 2E).

\section{Role of Brn-2 in Schwann cell development}

The coordinated expression of Brn-2 and Oct- 6 prompted our in vivo studies of Brn-2 as the additional overlapping activating factor in the Schwann cell developmental program. We found that overexpression of Brn-2 under control of the Oct-6 SCE in Oct-6-deficient Schwann cells results in an increase in the number of Schwann cells that enter the myelinating phase on schedule. Schwann cell-specific deletion of Brn-2 in an Oct-6-deficient background results in a phenotype that is much more severe than that observed in Oct- 6 single mutant animals, with Schwann cells arrested at the promyelin stage up to 120 $\mathrm{d}$ after birth. These results strongly suggest that Brn-2 shares a role with Oct-6 in Schwann cell development as a positive regulator of the promyelinating-myelinating transition, and identify Brn-2 as the proposed Oct- 6 like function in Oct-6 mutant animals (Jaegle and Meijer 1998).

Functional overlap, as demonstrated here for Brn-2 and Oct-6, is a common phenomenon among members of the same transcription factor family and has been described for, among others, members of the Gata and Sp1 family. Within the POU family of transcription factors, overlapping roles have been described for the closely related Brn-1 and Brn-2 genes in cortical neuron development (McEvilly et al. 2002; Sugitani et al. 2002). Functional overlap has also been described between Oct- 6 and the more distantly related $S k n-1 a / i$ POU gene, which are both required for proper differentiation of epidermal keratinocytes (Andersen et al. 1997). In our system, we tested whether the more divergent POU domain gene Brn-5 could functionally complement Oct-6. The choice of Brn-5 was motivated by the work of $\mathrm{Wu}$ and colleagues (2001), who demonstrated that Brn-5 is expressed in myelinating Schwann cells and is regulated independently of Oct- 6 . High levels of Brn-5 expression did not ameliorate the developmental delay phenotype of nerves in Oct-6-deficient animals. This is not due to a possible inhibitory function of Brn-5, as SCE-Brn-5/Oct-6 $6^{\Delta S C E /+}$ nerves were normally myelinated (data not shown).
Analysis of Brn-2 expression in Oct- 6 mutant animals and Brn-2 overexpression studies led us to the conclusion that quantitatively higher levels of Brn-2 protein are required to initiate myelination on schedule. These data, together with the fact that Brn-2 and Oct- 6 have very similar DNA-binding preferences, suggest that the differences in biological function between Brn-2 and Oct- 6 result mainly from differences in the affinities for interacting factors and/or the repertoire of interacting partners.

POU domain proteins are known to interact with members of the Sry box (Sox) transcription factor family. For example, the activation of the Fgf4 enhancer in ES cells depends on the synergistic interaction between Sox2 and Oct4 proteins (Ambrosetti et al. 1997). In glial cells it has been shown that Sox10 interacts synergistically with Oct- 6 , but not Brn-1 or Brn-2, to activate transcription when both proteins are bound to adjacent binding sites in an artificial enhancer (Kuhlbrodt et al. 1998a). Synergistic activation required the N-terminal region of Oct-6 and Sox10 (Kuhlbrodt et al. 1998b). Similarly, the oligodendrocyte-enriched Sox 11 protein synergizes with Brn2 and Brn-1, but not with Oct-6. Taken together, these data suggest that a specific POU/Sox code exists and postulates that specific POU proteins require specific Sox proteins to exhibit cooperative effects (Kuhlbrodt et al. 1998a,b). If indeed important target genes of Oct-6 in glial cells are regulated through interaction with Sox10, and the pair Brn-2/Sox11 is equivalent to Oct-6/Sox10, the developmental defect in Oct-6-deficient Schwann cells but not in oligodendrocytes (Bermingham et al. 1996) could be explained as follows: Oligodendrocytes express Brn-2/Sox11 in addition to Oct-6/ Sox10, whereas Schwann cells express Oct-6/Sox10 and Brn-2 but not Sox11. Further experiments are required to test this hypothesis.

Our data demonstrate that the promyelin-to-myelinating transition is regulated by Oct-6/Brn-2 function, but even in the absence of these POU factors, Schwann cells eventually do enter the myelinating phase of cell differentiation. This is not due to accumulation of Oct-6 protein expressed from the hypomorphic $\triangle$ SCE allele (Fig. 2E). Also, as Brn-2 deletion in the Schwann cell lineage is complete, mosaicism of Brn-2 expression cannot explain this delayed myelination (Fig. 5). Two observations are particularly important in understanding the roles of Oct-6 and Brn-2 in Schwann cell differentiation and why even in their absence myelination occurs. First, in the absence of Oct- 6 , entry into the myelinating phase is delayed and the kinetics of this transition are changed (Fig. 6B). Whereas $>80 \%$ of wild-type Schwann cells have entered the myelinating phase by $\mathrm{P} 8$, in the absence of Oct-6 it takes several weeks for the same number of Schwann cells to make this transition into the myelinating phase. In the absence of both Oct- 6 and Brn-2, this transition is even further protracted. Second, kinetics of this transition are Oct-6/Brn-2 dosage-dependent. In terms of transcriptional regulation, this suggests that Oct- 6 greatly increases the chance that its target genes become activated. The finding that in the absence of 
Oct- 6 and Brn-2 this chance is not zero indicates that these target genes are activated, albeit less effectively, through other transcription factors, possibly including the ubiquitous POU factor Oct-1.

Notwithstanding, the identification and characterization of Brn-2 and its in vivo role in Schwann cells have provided insight into the transcriptional network of myelination. These results will ultimately lead to a biochemical explanation of the different, yet overlapping roles of Oct- 6 and Brn-2 in Schwann cell development and possible intervention strategies to promote myelination in clinical therapeutic settings.

\section{Materials and methods}

\section{Gene targeting}

A 10.5-kb HindIII fragment of Brn-2 genomic sequences was isolated from a 129 ola ES cell-genomic phage library. Two restrictions sites (HindIII and AgeI) were generated by PCR at the ATG and used to insert a $5^{\prime} \operatorname{loxP}$ site. A second clone was generated containing the neomycin gene driven by a thymidine kinase (Pytk) promoter flanked by FRT sites. Next to the 3'FRT site we inserted a $3^{\prime}$ loxP sequence and an eGFP reporter gene. A 1.9-kb fragment containing FRT-Pytk-neomycin-FRT-loxPeGFP was isolated as a BglII fragment and cloned in a unique BamHI site in the Brn-2 $3^{\prime}$ untranslated region. We positioned a negative-selection marker gene, a thymidine kinase gene driven by the phosphoglycerate kinase-1 promoter (PGK-tk), downstream from the $3^{\prime}$ homology region.

SpeI-linearized DNA (15 $\mu \mathrm{g}$ ) was electroporated into E14 ES cells followed by selection with G418 $(200 \mu \mathrm{g} / \mathrm{mL})$ and $2 \mu \mathrm{M}$ gancyclovir. Individual clones were screened for homologous recombination by Southern-blot analysis of BamHI and HindIIIdigested genomic DNA with 5' and 3' external probes (probes A and B). One correctly targeted ES cell clone with a correct karyotype was isolated and injected into C57Bl/6 blastocysts. Male chimeric mice were mated with $\mathrm{FVB} / \mathrm{N}$ females to transmit the modified Brn-2 allele to the germ cells (Brn-2 $\left.{ }^{w t / f l o x}\right)$. Heterozygous offspring were back-crossed to generate homozygous mutant Brn-2 flox/flox mice. The different Brn-2 alleles were genotyped either by Southern blotting or by PCR with the following primers: 5'-GCGCGGCTCCTTTAACCAGAGCGCC-3' and 5'-CTGGTGAGCGTGGCTGAGCGGGTGC-3'. The wildtype allele will yield a 210-bp PCR product, and Brn-2 flox/flox will yield a 250-bp PCR product.

\section{Transgenic mice}

For the generation of Cre recombinase-expressing mice, we used an 18 -kb NotI Dhh genomic clone encompassing the Dhh promoter, exons 1, 2, and 3 (gift from Dr. Andy MacMahon, Harvard). The Cre gene was extended at its $\mathrm{N}$ terminus with a nuclear localization peptide sequence and cloned in exon 1 on the start codon of Dhh. The 19-kb transgene construct was separated from vector sequences and microinjected into fertilized $\mathrm{FVB} / \mathrm{N}$ oocytes. Founder lines were crossed back to FVB/N mice. The genotype of the mice was determined by PCR analysis of genomic DNA isolated from mouse tails. Cre-specific primers 5'-ACCCTGTTACGTATAGCCGA-3' and 5'-CTCC GGTATTGAAACTCCAG-3' were used to amplify a 300-bp fragment from the DhhCre construct.
The HA-tag expression cassette was generated by subcloning a $2.3-\mathrm{kb}$ NotI/HindIII fragment containing the HA-tagged Oct-6 fusion gene described before (Mandemakers et al. 2000) into pBluescript (pHA-Oct-6). A BglII/SpeI/NcoI synthetic polylinker was inserted as a blunt/NcoI fragment into MscI/NcoI-digested pHA-Oct-6, placing the linker just behind the triple HA tag and removing most of the Oct- 6 coding sequences (HA-tag cloning vector). A 2-kb BamHI fragment containing the Brn-2 coding sequence, isolated from pCMV-Brn-2, was subcloned into the HA-tag cloning vector linearized with BglII (HA-Brn-2). A 0.9-kb $\mathrm{BamHI} / \mathrm{XbaI}$ fragment containing Brn-5 coding sequences, isolated from pCMV-Brn-5, was cloned into the HA-tag cloning vector digested with BglII/SpeI (HA-Brn-5). The NotI/SwaI fragments from HA-Brn-2 and HA-Brn-5 were then ligated into NotI/SwaI-digested R3HAOct-6-SCE vector, creating constructs SCE-HABrn-2 and SCE-HABrn-5. EcoRI restriction fragments containing the transgene construct were isolated and microinjected into fertilized FVB/ $\mathrm{N}$ oocytes. Transgenic lines were crossed into an Oct- $6^{\triangle S C E / \triangle S C E}$ background.

\section{Electron microscopy}

Electron microscopy on sciatic nerves was performed as described (Jaegle et al. 1996). Mice were anesthetized with Nembutal and transcardially perfused with PBS followed by $3 \%$ paraformaldehyde (PFA) and $1 \%$ glutaraldehyde in $0.1 \mathrm{M}$ sodium cacodylate buffer at $\mathrm{pH}$ 7.5. Sciatic nerves were isolated and placed in fresh fixative overnight at $4^{\circ} \mathrm{C}$. The sciatic nerves were washed in $0.2 \mathrm{M}$ cacodylate buffer overnight at $4^{\circ} \mathrm{C}$ before being postfixed in $1 \% \mathrm{OsO}_{4}$ for $3 \mathrm{~h}$, dehydrated, and embedded in Epon. Semithin sections were stained with para-phenylenediamine (ppd; Estable-Puig et al. 1965) and viewed under an Olympus microscope. Ultrathin sections were stained with uranyl acetate and lead citrate, and analyzed with a Philips CM100 electron microscope. For quantification, five random nonoverlapping electron micrographs were produced for every nerve at a final magnification of 2600x. Myelinating and promyelin figures were counted (250-450 fibers per nerve).

\section{Whole-mount $X$-gal staining}

Embryos were isolated and fixed by immersion for $1 \mathrm{~h}$ at room temperature in $2 \%$ formaldehyde, $0.2 \%$ glutaraldehyde, $2 \mathrm{mM}$ $\mathrm{MgCl}_{2}, 5$ mM EGTA at pH 8, and $0.02 \%$ NP-40 in PBS. Embryos were washed three times for $10 \mathrm{~min}$ in PBS with $0.02 \% \mathrm{NP}-40$ and stained overnight at room temperature in PBS containing 1 $\mathrm{mg} / \mathrm{mL}$ Bluo-gal, $5 \mathrm{mM} \mathrm{K}_{3} \mathrm{Fe}(\mathrm{CN})_{6}, 5 \mathrm{mM} \mathrm{K}_{4} \mathrm{Fe}(\mathrm{CN})_{6}, 2 \mathrm{mM}$ $\mathrm{MgCl}_{2}, 0.01 \%$ SDS, and $0.02 \%$ NP-40. Subsequently, the stained embryos were washed twice in PBS with $0.02 \%$ NP40, postfixed overnight in $4 \%$ formaldehyde, and embedded into paraffin. Sections $(8 \mu \mathrm{m})$ were cut, counterstained with eosin, and viewed under the microscope. Images were collected using an Olympus DP50 digital camera.

\section{Antibodies and immunohistochemistry}

Rabbit polyclonal antibodies were raised against the $\mathrm{N}$ terminus of Brn-2 protein (amino acids 155-271). Animals were immunized with His-tagged fused protein expressed in Escherichia coli and purified on $\mathrm{Ni}^{2+}$-NTA-agarose beads (QIAGEN). Specificity of the Brn-2 antiserum was confirmed by EMSA (data not shown). Antibodies raised against the $\mathrm{N}$-terminal portion of the Oct-6 protein have been described (Ilia et al. 2002).

Sciatic nerves were isolated, teased into single fibers, and fixed for $30 \mathrm{~min}$ with $4 \%$ PFA at room temperature. The tissue was blocked in $1 \%$ BSA, $0.05 \%$ Tween- 20 in Tris-buffered sa- 
line (TBS). Rabbit anti-Brn-2 antibodies and mouse anti-Neurofilament (hybridoma 2H3, Developmental Studies Hybridoma Bank) antibodies, both diluted 1:200, were incubated simultaneously in TBS $/ 0.05 \%$ Tween-20 overnight at room temperature. Oregon Green-conjugated goat anti-rabbit IgGs (Molecular Probes) and Texas Red-conjugated goat anti-mouse IgGs (Molecular Probes) were subsequently used as secondary antibodies. The tissue was viewed using a Leica fluorescence microscope.

\section{Western blotting}

Sciatic nerves were isolated and directly lysed in loading buffer, followed by sonication and heating in a boiling water bath. Western blotting was performed as described (Ghazvini et al. 2002). Primary antibodies include anti-HA (rabbit polyclonal Y-11; Santa Cruz Biotechnology; used at dilution 1:2000), antiBrn-2 (goat polyclonal C-20; Santa Cruz Biotechnology; used at 1:100), anti-Oct-6 (rabbit polyclonal; 1:1000), anti-P-zero (mouse monoclonal, hybridoma clone P07; 1:1000 (Archelos et al. 1993), and acetylated $\alpha$-Tubulin (mouse monoclonal Sigma T-6793; 1:10,000). Secondary antibodies were either conjugated with alkaline phosphatase (Dako) or horseradish peroxidase (Dako) for the detection of primary antibodies.

\section{Electrophoretic mobility shift assay}

Sciatic nerve and Schwann cell extracts were prepared by placing the tissue or cells in 5-10 tissue volumes of $20 \mathrm{mM}$ Hepes$\mathrm{KOH}$ at $\mathrm{pH} 7.9,400 \mathrm{mM} \mathrm{KCl}, 1 \mathrm{mM}$ EDTA, $10 \mathrm{mM}$ DTT, $10 \%$ glycerol supplemented with $1 \mathrm{mM}$ PMSF, and $1 \times$ protease inhibitor cocktail (Sigma; Meijer et al. 1992). The tissue was disrupted by four cycles of snap-freezing in liquid nitrogen and thawing on ice. Cellular debris was removed by centrifugation at $14000 \mathrm{~g}$ for $5 \mathrm{~min}$ at $4^{\circ} \mathrm{C}$. The supernatant was snap-frozen and stored in aliquots at $-80^{\circ} \mathrm{C}$. Equal amounts of extract were used in a bandshift assay using 10 fmole of a ${ }^{32} \mathrm{P}$ end-labeled double-strand oligonucleotide probe (GAGAGGA CATTTCCACCGACCTTCC). Probe and protein were incubated on ice, in the absence or presence of antiserum, for $20 \mathrm{~min}$ in $20 \mathrm{mM}$ Hepes- $\mathrm{KOH}$ at $\mathrm{pH} 7.9,1 \mathrm{mM}$ EDTA, $1 \mathrm{mM}$ EGTA, $4 \%$ Ficoll in a total volume of $20 \mu \mathrm{L}$. Complexed and free probe were separated on a $4 \%$ polyacrylamide gel in $0.25 \times$ TBE electrophoresis buffer at room temperature. Gels were fixed in $10 \%$ methanol/10\% acetic acid, dried, and exposed to a PhosphorImager screen (Molecular Dynamics). Relative band intensities were calculated using the ImageQuant 5.2 software.

\section{Acknowledgments}

We thank Elaine Dzierzak and Sjaak Philipsen for their comments and encouragement. John Kong a San is thanked for his expert help in microinjection, Manoussos Koutsourakis for blastocyst injection, and Matthijs Uyl and Ludo Broos for help in immunohistochemistry. The genomic Dhh clone was a kind gift from Dr. Andy MacMahon (Harvard University, Boston). The $2 \mathrm{H} 3$ monoclonal antibody, developed by T.M. Jessell and J. Dodd, was obtained from the Developmental Studies Hybridoma Bank developed under auspices of the NICHD and maintained by The University of Iowa, Department of Biological Sciences. The monoclonal P07 against the extra-cellular domain of P-zero was a kind gift from Dr. Juan Archelos (Graz University, Austria). This work was supported in part by grants from the Dutch Research Council NWO (ALW 805-17.281 and MW 90342-195).
The publication costs of this article were defrayed in part by payment of page charges. This article must therefore be hereby marked "advertisement" in accordance with 18 USC section 1734 solely to indicate this fact.

\section{References}

Ambrosetti, D.C., Basilico, C., and Dailey, L. 1997. Synergistic activation of the fibroblast growth factor 4 enhancer by Sox 2 and Oct- 3 depends on protein-protein interactions facilitated by a specific spatial arrangement of factor binding sites. Mol. Cell. Biol. 17: 6321-6329.

Andersen, B., Weinberg, W.C., Rennekampff, O., McEvilly, R.J., Bermingham Jr., J.R., Hooshmand, F., Vasilyev, V., Hansbrough, J.F., Pittelkow, M.R., Yuspa, S.H., et al. 1997. Functions of the POU domain genes Skn-1a/i and Tst-1/Oct-6/ SCIP in epidermal differentiation. Genes \& Dev. 11: 18731884.

Archelos, J.J., Roggenbuck, K., Schneider-Schaulies, J., Linington, C., Toyka, K.V., and Hartung, H.P. 1993. Production and characterization of monoclonal antibodies to the extracellular domain of P0. J. Neurosci. Res. 35: 46-53.

Arroyo, E.J. and Scherer, S.S. 2000. On the molecular architecture of myelinated fibers. Histochem. Cell. Biol. 113: 1-18.

Arroyo, E.J., Bermingham Jr., J.R., Rosenfeld, M.G., and Scherer, S.S. 1998. Promyelinating Schwann cells express Tst-1/ SCIP/Oct-6. J. Neurosci. 18: 7891-7902.

Bermingham, J.R., Scherer, S.S., O'Connell, S., Arroyo, E., Kalla, K.A., Powell, F.L., and Rosenfeld, M.G. 1996. Tst-1/Oct-6/ SCIP regulates a unique step in peripheral myelination and is required for normal respiration. Genes \& Dev. 10: 17511762.

Bitgood, M.J. and McMahon, A.P. 1995. Hedgehog and Bmp genes are coexpressed at many diverse sites of cell-cell interaction in the mouse embryo. Dev. Biol. 172: 126-138.

Blanchard, A.D., Sinanan, A., Parmantier, E., Zwart, R., Broos, L., Meijer, D., Meier, C., Jessen, K.R., and Mirsky, R. 1996. Oct-6 (SCIP/Tst-1) is expressed in Schwann cell precursors, embryonic Schwann cells, and postnatal myelinating Schwann cells: Comparison with Oct-1, Krox-20, and Pax-3. J. Neurosci. Res. 46: 630-640.

Britsch, S., Goerich, D.E., Riethmacher, D., Peirano, R.I., Rossner, M., Nave, K.A., Birchmeier, C., and Wegner, M. 2001. The transcription factor Sox 10 is a key regulator of peripheral glial development. Genes \& Dev. 15: 66-78.

Estable-Puig, J.F., Bauer, W.C., and Blumberg, J.M. 1965. Technical note; paraphenylenediamine staining of osmium-fixed plastic embedded tissue for light and phase microscopy. $J$. Neuropathol. Exp. Neurol. 24: 531-536.

Fields, R.D. and Stevens-Graham, B. 2002. New insights into neuron-glia communication. Science 298: 556-562.

Ghazvini, M., Mandemakers, W., Jaegle, M., Piirsoo, M., Driegen, S., Koutsourakis, M., Smit, X., Grosveld, F., and Meijer, D. 2002. A cell type-specific allele of the POU gene Oct-6 reveals Schwann cell autonomous function in nerve development and regeneration. EMBO J. 21: 4612-4620.

Ghislain, J., Desmarquet-Trin-Dinh, C., Jaegle, M., Meijer, D., Charnay, P., and Frain, M. 2002. Characterization of cisacting sequences reveals a biphasic, axon-dependent regulation of Krox20 during Schwann cell development. Development 129: 155-166.

Hudson, L.D. 2001. Control of gene expression by oligodendrocytes. In Glial cell development (eds. K.R. Jessen, W.D. Richardson), pp. 209-222. Oxford University Press, Oxford, UK. 
Ilia, M., Beasley, C., Meijer, D., Kerwin, R., Cotter, D., Everall, I., and Price, J. 2002. Expression of Oct-6, a POU III domain transcription factor, in schizophrenia. Am. J. Psychiatry 159: $1174-1182$.

Jaegle, M. and Meijer, D. 1998. Role of Oct-6 in Schwann cell differentiation. Microsc. Res. Tech. 41: 372-378.

Jaegle, M., Mandemakers, W., Broos, L., Zwart, R., Karis, A., Visser, P., Grosveld, F., and Meijer, D. 1996. The POU factor Oct-6 and Schwann cell differentiation. Science 273: 507510.

Kuhlbrodt, K., Herbarth, B., Sock, E., Enderich, J., HermansBorgmeyer, I., and Wegner, M. 1998a. Cooperative function of POU proteins and SOX proteins in glial cells. J. Biol. Chem. 273: 16050-16057.

Kuhlbrodt, K., Herbarth, B., Sock, S., Hermans-Borgmeyer, I., and Wegner, M. 1998b. Sox10, a novel transcriptional modulator in glial cells. J. Neurosci. 18: 237-250.

Kuhn, R., Monuki, E.S., and Lemke, G. 1991. The gene encoding the transcription factor SCIP has features of an expressed retroposon. Mol. Cell. Biol. 11: 4642-4650.

Le Douarin, N.M. and Kalcheim, C. 1999. The neural crest, pp. 328-335. Cambridge University Press, Cambridge, UK.

Levavasseur, F., Mandemakers, W., Visser, P., Broos, L., Grosveld, F., Zivkovic, D., and Meijer, D. 1998. Comparison of sequence and function of the Oct- 6 genes in zebrafish, chicken, and mouse. Mech. Dev. 74: 89-98.

Mandemakers, W., Zwart, R., Jaegle, M., Walbeehm, E., Visser, P., Grosveld, F., and Meijer, D. 2000. A distal Schwann cellspecific enhancer mediates axonal regulation of the Oct-6 transcription factor during peripheral nerve development and regeneration. EMBO J. 19: 2992-3003.

McEvilly, R.J., de Diaz, M.O., Schonemann, M.D., Hooshmand, F., and Rosenfeld, M.G. 2002. Transcriptional regulation of cortical neuron migration by POU domain factors. Science 295: $1528-1532$.

Meijer, D., Graus, A., Kraay, R., Langeveld, A., Mulder, M.P., and Grosveld, G. 1990. The octamer binding factor Oct6: cDNA cloning and expression in early embryonic cells. Nucleic Acids Res. 18: 7357-7365.

Meijer, D., Graus, A., and Grosveld, G. 1992. Mapping the transactivation domain of the Oct6 POU transcription factor. Nucleic Acids Res. 20: 2241-2247.

Mirsky, R., Jessen, K.R., Brennan, A., Parkinson, D., Dong, Z., Meier, C., Parmantier, E., and Lawson, D. 2002. Schwann cells as regulators of nerve development. J. Physiol. Paris 96: $17-24$.

Nagarajan, R., Svaren, J., Le, N., Araki, T., Watson, M., and Milbrandt, J. 2001. EGR2 mutations in inherited neuropathies dominant-negatively inhibit myelin gene expression. Neuron 30: 355-368.

Nakai, S., Kawano, H., Yudate, T., Nishi, M., Kuno, J., Nagata, A., Jishage, K., Hamada, H., Fujii, H., Kawamura, K., et al. 1995. The POU domain transcription factor Brn-2 is required for the determination of specific neuronal lineages in the hypothalamus of the mouse. Genes \& Dev. 9: 3109-3121.

Nickols, J.C., Valentine, W., Kanwal, S., and Carter, B.D. 2003. Activation of the transcription factor NF- $\mathrm{B}$ in Schwann cells is required for peripheral myelin formation. Nat. Neurosci. 6: 161-167.

Richardson, W.D. 2001. Oligodendrocyte development. In Glial cell development (eds. K.R. Jessen and W.D. Richardson), pp. 21-54. Oxford University Press, Oxford.

Ryan, A.K. and Rosenfeld, M.G. 1997. POU domain family values: Flexibility, partnerships, and developmental codes. Genes \& Dev. 11: 1207-1225.

Scherer, S.S., Wang, D.Y., Kuhn, R., Lemke, G., Wrabetz, L., and
Kamholz, J. 1994. Axons regulate Schwann cell expression of the POU transcription factor SCIP. J. Neurosci. 14: 19301942 .

Schonemann, M.D., Ryan, A.K., McEvilly, R.J., O'Connell, S.M., Arias, C.A., Kalla, K.A., Li, P., Sawchenko, P.E., and Rosenfeld, M.G. 1995. Development and survival of the endocrine hypothalamus and posterior pituitary gland requires the neuronal POU domain factor Brn-2. Genes \& Dev. 9: 3122-3135.

Sim, F., Zhao, C., Li, W., Lakatos, A., and Franklin, R. 2002. Expression of the POU-domain transcription factors SCIP/ Oct-6 and Brn-2 is associated with Schwann cell but not oligodendrocyte remyelination of the CNS. Mol. Cell. Neurosci. 20: 669.

Soriano, P. 1999. Generalized lacZ expression with the ROSA26 Cre reporter strain. Nat. Genet. 21: 70-71.

Sugitani, Y., Nakai, S., Minowa, O., Nishi, M., Jishage, K., Kawano, H., Mori, K., Ogawa, M., and Noda, T. 2002. Brn-1 and Brn-2 share crucial roles in the production and positioning of mouse neocortical neurons. Genes \& Dev. 16: 1760 1765.

Topilko, P. and Meijer, D. 2001. Transcription factors that control Schwann cell development and myelination. In Glial cell development (eds. K.R. Jessen and W.D. Richardson), pp. 223-244. Oxford University Press, Oxford.

Topilko, P., Schneider-Maunoury, S., Levi, G., Baron-Van Evercooren, A., Chennoufi, A.B., Seitanidou, T., Babinet, C., and Charnay, P. 1994. Krox-20 controls myelination in the peripheral nervous system. Nature 371: 796-799.

Waragai, M., Lammers, C.H., Takeuchi, S., Imafuku, I., Udagawa, Y., Kanazawa, I., Kawabata, M., Mouradian, M.M., and Okazawa, H. 1999. PQBP-1, a novel polyglutamine tractbinding protein, inhibits transcription activation by Brn-2 and affects cell survival. Hum. Mol. Genet. 8: 977-987.

Webster, H.d. 1993. Development of peripheral nerve fibers. In Peripheral neuropathy (eds. P.J. Dyck, P.K. Thomas, J.W. Griffin, P.A. Low, and J.F. Poduslo), pp. 243-266. W.B. Saunders, Philadelphia.

Wu, R., Jurek, M., Sundarababu, S., and Weinstein, D.E. 2001. The POU gene Brn-5 is induced by neuregulin and is restricted to myelinating Schwann cells. Mol. Cell. Neurosci. 17: 683-695. 


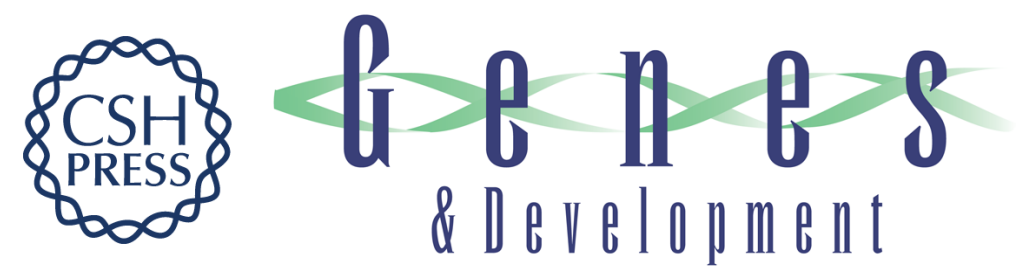

\section{The POU proteins Brn-2 and Oct- 6 share important functions in Schwann cell development}

Martine Jaegle, Mehrnaz Ghazvini, Wim Mandemakers, et al.

Genes Dev. 2003, 17:

Access the most recent version at doi:10.1101/gad.258203

References This article cites 37 articles, 17 of which can be accessed free at: http://genesdev.cshlp.org/content/17/11/1380.full.html\#ref-list-1

License

Email Alerting

Receive free email alerts when new articles cite this article - sign up in the box at the top Service right corner of the article or click here.

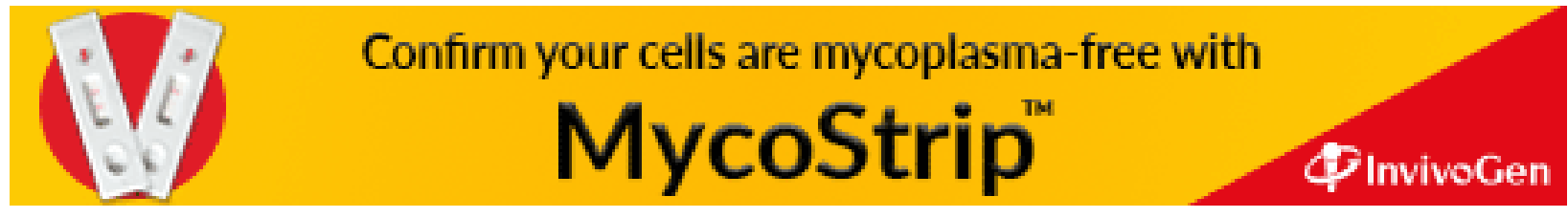

